\title{
Associative learning changes the organization of functional excitatory circuits targeting the supragranular layers of mouse barrel cortex
}

\author{
Céline Rosselet ${ }^{1,2}$, Maxime Fieschi ${ }^{1,2}$, Sandrine Hugues ${ }^{1,2}$ and Ingrid Bureau ${ }^{1,2 *}$ \\ INSERM, U901 INMED, Marseille, France \\ 2 Université de la Méditerranée, UMR S901 Aix-Marseille 2, Marseille, France
}

\section{Edited by:}

Takao K. Hensch,

Harvard University, USA

Reviewed by:

Gordon M. G. Shepherd,

Northwestern University, USA

Carl Petersen, Ecole Polytechnique

Fédérale de Lausanne, Switzerland

Gerald Finnerty, King's College London,

UK

${ }^{*}$ Correspondence:

Ingrid Bureau, INMED, 163 Route de

Luminy, 13273 Marseille, France.

e-mail: ingrid.bureau@inmed.univ-mrs.fr
In primary sensory cortices, neuronal circuits change throughout life as a function of learning. During associative learning a neutral sensory stimulus acquires the emotional valence of an aversive event or a reward after repetitive contingent pairing. One important consequence is the enlargement of the representational area of the conditioned stimulus in the cortical map of its sensory modality. The details of this phenomenon at the circuit level are still largely unknown. Here, mice were trained in a differential conditioning paradigm where the deflections of one whisker row were paired with tail shocks and the deflections of two others were not. Changes occurring in excitatory circuits of barrel cortex were then examined in brain slices with laser scanning photostimulation mapping. We found that learning affected the projections targeting the supragranular layers in the columns of unpaired whiskers: Pyramidal cells located in layer $(L) 3$ received enhanced inputs from L5A cells located in their home column and new inputs from L2/3 and L4 cells located in the neighboring column of the paired whisker. In contrast, the excitatory projections impinging onto $L 2 / 3$ cells in the column of the paired whisker were not altered. Together, these data reveal that associative learning alters the canonical columnar organization of functional ascending $L 4$ projections and strengthens transcolumnar excitatory projections in barrel cortex. These phenomena could participate to the transformation of the whisker somatotopic map induced by associative learning.

Keywords: synaptic connectivity, cortical circuits, glutamate uncaging, layer 2/3, fear conditioning

\section{INTRODUCTION}

Behavioral conditioning leads to plasticity in the primary sensory cortex of the conditioned stimulus (CS) sensory modality: receptive fields of cortical neurons shift in such manner that the area responding to the CS is enlarged (reviewed in Weinberger, 2004). Thus, tagging stimuli with emotional significance transforms the cortical sensory maps. Although this phenomenon was observed across sensory modalities and for various conditioning paradigms (reviewed in Edeline, 1999), the precise identity of neuronal circuits underlying the plasticity of cortical maps is largely unknown.

Primary sensory cortices are organized in arrays of columns that are arranged orthogonally to the pia and where neurons are tuned to one sensory organ or one dimension of a sensory modality (Mountcastle, 1957; Hubel and Wiesel, 1962). Neurons in each column of barrel cortex, a region of the primary somatosensory cortex, are tuned to one principal whisker. The spatial arrangement of cortical columns is somatotopic such that neighboring columns correspond to neighboring whiskers on the snout of the animal. Barrel cortex is particularly suited to the study of circuits because of the presence of cell aggregates in layer (L) 4 (Woolsey and Loos, 1970), the barrels, which are optically dense in brain slices and provide natural landmarks for identifying the columns in vitro.

Previous measurements with markers of neuronal activity showed that classical conditioning with the deflection of one whisker row as CS enlarged the representation of that particular row in the whisker somatotopic map (Siucinska and Kossut, 1996, 2004; Galvez et al., 2006). These approaches pointed at layers and columns of barrel cortex where plasticity occurred but the full spectrum of connections it involved is still unresolved. The pattern of cortical circuits is complex and neurons in any given layer are involved in multiple local and longer-range connections. Hence, multiple circuits could sustain the transformation of the whisker somatotopic map, but so far only L4 inhibitory neurons were clearly implicated (Siucinska et al., 1999; Gierdalski et al., 2001; Tokarski et al., 2007).

Excitatory circuits targeting the supragranular layers 2 and 3 of barrel cortex have been the object of intense investigations owing to their plasticity in developing and adult brains (Fox, 1992; Finnerty et al., 1999; Allen et al., 2003; Shepherd et al., 2003). Major inputs received by L2/3 pyramidal cells originate from L 4 cells located in the barrel of their home column (Petersen and Sakmann, 2001; Shepherd et al., 2003). This columnar organization is matched by the anatomy of $\mathrm{L} 4 \rightarrow \mathrm{L} 2 / 3$ connections which are largely confined within one column (Lubke et al., 2003). Other excitatory inputs originate from L5A and L2/3 cells. Both cell types have axonal arborizations spreading out widely in L2/3 (Feldmeyer et al., 2005, 2006; Shepherd and Svoboda, 2005) which allows them to connect neurons located in their home column and in neighboring columns. Although the transcolumnar projections are functionally weak in naive animals, they are strengthened in experiments designed to unbalance the use of whiskers (Finnerty et al., 1999). 
One hypothesis is that the transformation of the whisker cortical map induced by associative learning depends on a similar plasticity, strengthening the projections that originate in the column of CS and terminate in neighboring columns of unpaired whiskers. To test this possibility and compare the effects of associative learning on columnar and transcolumnar circuits of barrel cortex, we conditioned mice and investigated the strength of excitatory projections impinging onto L2/3 pyramidal cells in brain slices with laser scanning photostimulation (LSPS; Callaway and Katz, 1993; Shepherd et al., 2003). We found that training mice in a differential conditioning where one whisker row was paired $\left(\mathrm{CS}^{+}\right)$with a shock and two other rows were unpaired $\left(\mathrm{CS}^{-}\right)$induced plasticity in all L4, L2/3, and L5A projections connecting L2/3 cells located in columns of unpaired whiskers. We discuss their potential for propagating $\mathrm{CS}^{+}$inputs.

\section{MATERIALS AND METHODS FEAR CONDITIONING AND CARDIAC RESPONSE ANALYSIS}

Experiments followed institutional guidelines of INSERM. Fear conditioning was induced in awake, head-restrained, 4-week-old C57Bl6 male mice (Janvier). Three days prior training, a holding element $(0.38 \mathrm{~g})$ was cemented on the skull of the anesthetized animal (ketamine/xylazine, 200/20 $\mathrm{mg} \mathrm{kg}^{-1}$, intra muscular) and two clips were attached to the skin of its chest. Whiskers were bilaterally trimmed down to $\sim 1 \mathrm{~cm}$ to ease their stimulation. Training of conditioned mice $(n=31)$ was over 5 days with 2 days of habituation and three of conditioning. Daily training and testing sessions lasted 20 min maximum and were aborted when the mouse became visibly agitated, pushing its body forward. Each whisker row was individually deflected with three strokes of a fine paint brush moved manually $(\sim 1.2 \mathrm{~Hz})$ in the caudo-rostral direction (Siucinska and Kossut, 1996). Only the rows A, B, or C were deflected. The sequence was pseudo-random without repetition and had random time intervals between 16 and $45 \mathrm{~s}$. On conditioning days, the stimulation of the $\mathrm{C}$ row was terminated with an electrical shock $(100 \mu \mathrm{A}$, $250 \mathrm{~ms}$ ) delivered to the tail. Shock occurred at the offset of whisker stimulation. During each habituation day and the first conditioning day $\mathrm{A}, \mathrm{B}$, and $\mathrm{C}$ whisker rows were stimulated 12 times each. The number of $C$ whisker stimulations decreased to eight on the second conditioning day and to six on the third. This was designed to make the pairing of the $\mathrm{C}$ whisker deflections with tail shocks more salient and prevent generalization. Each animal was shocked 26 times maximum over 3 days. Associative learning was assessed 3-7 days after the last conditioning session in the same apparatus used for conditioning. Mouse electrocardiograms were then monitored through the two clips and whisker rows were individually deflected, without tail shock.

Inter-heartbeat intervals of conditioned mice were computed in $500 \mathrm{~ms}$ bins. Traces of 5-12 trials (average, 6.5) were then averaged to measure the cardiac response for each whisker row. The amplitude of cardiac response was measured at the peak within a 10-s time window after whisker deflection. An increase of the inter-heartbeat intervals indicated a bradycardia. The threshold of a significant bradycardia was two times the standard deviation of baseline. The selectivity index of cardiac responses was computed based on the relative amplitude of the evoked bradycardias as follow:

$100 \times a m p^{X} /\left(a m p^{A}+a m p^{B}+a m p^{C}\right)$.
Where amp is the amplitude of bradycardia and $\mathrm{X}$ is the row of whisker A, B, or C.

Pseudoconditioned mice $(n=6)$ received the same number of whisker stimulations and tail shocks during training as the conditioned mice, but their occurrences were temporally uncorrelated with each other. Naive mice $(n=15)$ received the same surgery and holding element but they were not manipulated until brain slices were prepared.

\section{BRAIN SLICE PREPARATION AND LSPS MAPPING}

Conditioned mice were anesthetized and sacrificed within $1 \mathrm{~h}$ after the testing session. Across-row barrel cortex slices ( $300 \mu \mathrm{m}$ thick) were prepared as described (Finnerty et al., 1999) in a chilled solution containing (in $\mathrm{mM}$ ): 110 choline chloride, $25 \mathrm{NaHCO}_{3}, 25$ D-glucose, 11.6 sodium ascorbate, $7 \mathrm{MgCl}_{2}, 3.1$ sodium pyruvate, $2.5 \mathrm{KCl}, 1.25 \mathrm{NaH}_{2} \mathrm{PO}_{4}$, and $0.5 \mathrm{CaCl}_{2}$. Slices were transferred to artificial cerebrospinal fluid (ACSF) containing (in $\mathrm{mM}$ ): $127 \mathrm{NaCl}$, $25 \mathrm{NaHCO}_{3}, 25$ D-glucose, $2.5 \mathrm{KCl}, 1 \mathrm{MgCl}_{2}, 2 \mathrm{CaCl}_{2}$, and 1.25 $\mathrm{NaH}_{2} \mathrm{PO}_{4}$, aerated with $95 \% \mathrm{O}_{2}$ and $5 \% \mathrm{CO}_{2}$, first at $34^{\circ} \mathrm{C}$ for $15 \mathrm{~min}$ and then at room temperature prior to use. ACSF was complemented with (in mM) 0.2 MNI-caged glutamate (Tocris), 0.005 ( \pm )-CPP (Sigma) an antagonist of NMDA receptors, $4 \mathrm{CaCl}_{2}$ and $4 \mathrm{MgCl}_{2}$ for LSPS mapping Recording were performed at room temperature in the two most medial slices containing five A-E barrels. Neurons $84 \pm 2 \mu \mathrm{m}$ deep in the slice were patched using borosilicate electrodes (4-6 M $\Omega$ ) filled with intracellular solution containing (in $\mathrm{mM}$ ): 128 K-methylsulfate, $4 \mathrm{MgCl}_{2}, 10 \mathrm{HEPES}, 1$ EGTA, $4 \mathrm{Na}_{2} \mathrm{ATP}, 0.4 \mathrm{Na}_{2} \mathrm{GTP}$, $10 \mathrm{Na}$-phosphocreatine, 3 ascorbic acid; $\mathrm{pH}$ 7.25. Traces of wholecell voltage-clamp recordings were filtered at $5 \mathrm{kHz}$ and sampled at $10 \mathrm{kHz}$. Focal photolysis of caged glutamate was accomplished with a 2-ms $20 \mathrm{~mW}$ pulse of a UV laser (DPSS Lasers Inc.) through a $4 \times$ objective. The stimulus pattern consisted of 324 positions on a $18 \times 18$ grid (75 $\mu \mathrm{m}$ spacing). The uncaging grid was centered vertically on the barrel B or C. The 10th and 11th lines were above L4 and L5A, respectively. UV stimuli were presented once every $700 \mathrm{~ms}$ in a spatial order designed to avoid consecutive glutamate uncaging at neighboring sites (Shepherd et al., 2003). Custom softwares for instrument control and acquisition (www.ephus.org; Suter et al., 2010) were written in Matlab (MathWorks, Inc.).

Synaptic input maps for individual neurons were constructed by computing the mean current amplitude in a 50-ms time window $6 \mathrm{~ms}$ after the UV stimulus for each location of photostimulation. Two to four maps were obtained per cell and averaged (Figure 2B). Averaged single-cell maps were used to compute group-averaged maps (Figures 2D,E). Interpolation was performed on averaged synaptic input maps for display purposes. The center of mass of synaptic input feeding into L2/3 cells was calculated as $\Sigma$ (synaptic input $\times$ lateral distance from the center of column) $/ \Sigma$ (synaptic input). Positive values indicate a shift to the right from the center of the home column.

Excitation profiles of layer (L) 2/3, L4, and L5A cells were evaluated with loose-seal recordings. These measure the evoked excitation and mapping resolution of LSPS. Glutamate was uncaged on an $8 \times 8$ grid (50 $\mu \mathrm{m}$ spacing) centered on somas and action potentials (APs) were counted at each uncaging site. L2/3 pyramidal cells $(n=16)$ spiked a total number of $3.8 \pm 0.5$ APs over the entire grid. This number was $3.4 \pm 0.6$ for L4 stellate cells $(n=18)$ and $6.4 \pm 0.9$ for 
L5A pyramidal cells $(n=16)$. The mean vertical distance of excitation calculated as $\Sigma($ APs $\times$ absolute distance from the soma) $/ \Sigma$ (APs) was $42 \pm 3 \mu \mathrm{m}$ for L2/3 cells, $43 \pm 6 \mu \mathrm{m}$ for L 4 cells and $40 \pm 5 \mu \mathrm{m}$ for L5A cells. This distance along the horizontal axis was $35 \pm 2 \mu \mathrm{m}$ for L2/ 3 cells, $36 \pm 3 \mu \mathrm{m}$ for L4 cells, and $43 \pm 3 \mu \mathrm{m}$ for L5A cells. Based on these excitation profiles and the neuronal density measured in (Bureau et al., 2008), we estimate the number of spiking neurons per uncaging site at $\sim 45$ in barrels and in L2/3 (see supplementary methods in Weiler et al., 2008). Note that the number of neurons that are directly connected to the postsynaptic cell is lower.

Group values are indicated as mean \pm SEM. The statistical $p$ values are from Mann-Whitney tests, unless stated otherwise. Error bars in figures are SEM.

\section{RESULTS THE DEFLECTIONS OF PAIRED WHISKERS EVOKE FEAR RESPONSES IN CONDITIONED MICE}

To draw correlations between associative learning and the plasticity of L2/3 circuits in barrel cortex, mice were trained in a differential conditioning paradigm where they were presented with three stimuli: the $\mathrm{C}$ row deflections $\left(\mathrm{CS}^{+}\right)$predicted the occurrence of a tail shock and the A, B row deflections $\left(\mathrm{CS}^{-}\right)$ predicted its absence. This protocol was preferred over classical conditioning where a single stimulus is conditioned because the latter was shown to have only modest effects on neuronal activity in L2/3 (Siucinska and Kossut, 1996) and we hypothesized that a complex task should recruit a large ensemble of cortical circuits. Moreover, the generation of a large distribution of behavioral performances caused by a complex task provides additional ways for evaluating the correlations between associative learning and plasticity in cortical circuits.

Learning was assessed 3-7 days after conditioning by measuring cardiac responses (Martin and Fitzgerald, 1980; Marchand, 2002) in a 10-s time window following the deflections of A, B, and $C$ rows (Figure 1A). Animals were first sorted according to their fear response evoked by $\mathrm{CS}^{+}$, the $\mathrm{C}$ whiskers. Mice were restrained and as a consequence this response was a slowing down of their heart rate (Martin and Fitzgerald, 1980), or bradycardia, measured here as an increase of the heartbeat time intervals. About $50 \%$ of the conditioned mice showed a bradycardia evoked by $\mathrm{C}$ row deflections (Brady ${ }^{+}$mice, $n=15$; Figures $1 \mathrm{~B}, \mathrm{C}$ ) while others did not (Brady- $n=16$; Figure 1D). Brady ${ }^{+}$and Brady mice were tested after similar delays following the last conditioning session ( $4.5 \pm 0.3$ and $4.0 \pm 0.2$ days, respectively). Heart rate accelerations could follow (Figure 1B) or precede (Figure 1C) the bradycardias in Brady ${ }^{+}$mice. They corresponded to brief periods of mouse agitation and, unlike bradycardias, were non-selective for the $\mathrm{CS}^{+}$. On average, heartbeat time intervals increased by $2.12 \pm 0.28 \mathrm{~ms}$ at the peak, a variation corresponding to a bradycardia of $-20 \pm 2 \mathrm{bpm}$ (range, -5 to $-46 \mathrm{bpm}$ ). Bradycardias were short-lasting (0.5-4.5 s above threshold; average $1.5 \pm 0.3 \mathrm{~s})$ and peaked $3.9 \pm 0.5 \mathrm{~s}$ (range, 1.3-7.3 s) after the onset of the $\mathrm{C}$ whisker deflections (Figures 1B,C).

These bradycardias resulted from associative learning because they were not seen in the group of pseudoconditioned mice (peak heart rate deceleration, $-3 \pm 1 \mathrm{bpm} ; n=6$ ) for which whisker deflections and shocks were not contingently paired during training.
The selectivity of the CS/shock association was analyzed in more details in the Brady ${ }^{+}$group of mice. Five animals had a bradycardia at the deflection of the $\mathrm{C}$ whiskers only, whereas ten had also smaller $(p<0.02$, Wilcoxon) but above threshold bradycardias evoked by A or B whiskers or both (Figures 1B,E). Baseline heart rates measured before A, B, and C trials were similar (Figure 1F) indicating that a lack or a weaker bradycardia evoked by A or B whiskers was not due to a floor effect. The specificity index of the cardiac response measured as the percentage of the $\mathrm{C}$-evoked bradycardia over the summed A to C-evoked cardiac responses ranged between 38 and $67 \%$ (average, $50 \pm 2 \%$; see Materials and Methods), hence between chance level (33\%) and perfect discrimination (100\%). Thus, differential conditioning generated here animals with a diversity of learning performances against which changes in L2/3 circuitry could next be compared.

\section{PLASTICITY OF INTRACORTICAL CIRCUITS AFTER DIFFERENTIAL CONDITIONING}

We first compared the pattern of functional excitatory projections impinging onto layer $2 / 3$ neurons between naive and $\mathrm{Brady}^{+}$mice. To this end, we recorded from L2/3 neurons in brain slices and used LSPS to map their projections (Callaway and Katz, 1993; Shepherd et al., 2003). This method enables localizing neurons that are presynaptic to a recorded cell with a few tens micrometer precision and surveying the strength of their connections simultaneously.

Brain slices were prepared to contain the five barrels corresponding to the A-E whisker rows (Figure 2A). Pyramidal cells in L2/3 were recorded in whole-cell voltage-clamp at $-70 \mathrm{mV}$, near the reversal potential of inhibitory currents (Bureau et al., 2008), to isolate the excitatory component of synaptic responses. The presynaptic neurons were stimulated with laser scanning glutamate uncaging on an $18 \times 18$ grid $(75 \mu \mathrm{m}$ spacing) aligned with the barrels. Spiking in presynaptic cells occurred only when glutamate was uncaged on cell bodies and proximal dendrites, at a mean distance of $\sim 40 \mu \mathrm{m}$ from the soma (see Materials and Methods). Connections between presynaptic neurons and the recorded cell were detected at sites where stimulation evoked excitatory postsynaptic currents (Figure 2B). Synaptic responses were quantified as the mean current amplitude in a 50-ms time window starting $6 \mathrm{~ms}$ after the stimulus (Figure 2C), and were used to build a color coded input map for each cell.

In naive mice, $\mathrm{L} 2 / 3$ pyramidal cells received strong inputs from L4 neurons located in the barrel below ( $n=28$; Figure 2D; Bureau et al., 2006; Lefort et al., 2009). Synaptic input maps recorded from the $\mathrm{B}$ and $\mathrm{C}$ columns were pooled together in the naive group of mice $(B / C, 17 / 11)$ as they did not show any significant difference $(p>0.9)$, but they were analyzed separately in the Brady ${ }^{+}$group to examine the effects of learning in columns of paired and unpaired whiskers. We mapped the synaptic projections impinging onto L2/3 cells located in the B column, adjacent to the paired C column in $\mathrm{Brady}^{+}$mice. We found that conditioning enhanced inputs originating from L2/3 and L5A ( $n=19$; Figures $2 \mathrm{E}, \mathbf{F}$ ). In contrast, the L4 inputs originating from the upper two-thirds of the $\mathrm{B}$ barrel were not altered ( $p=0.7$; Figure $2 \mathrm{~F}$ ). We did not analyze the inputs evoked by photo stimulations in the lower third of barrels because the excitation of L4 and L5A cells could not be separated there, as 


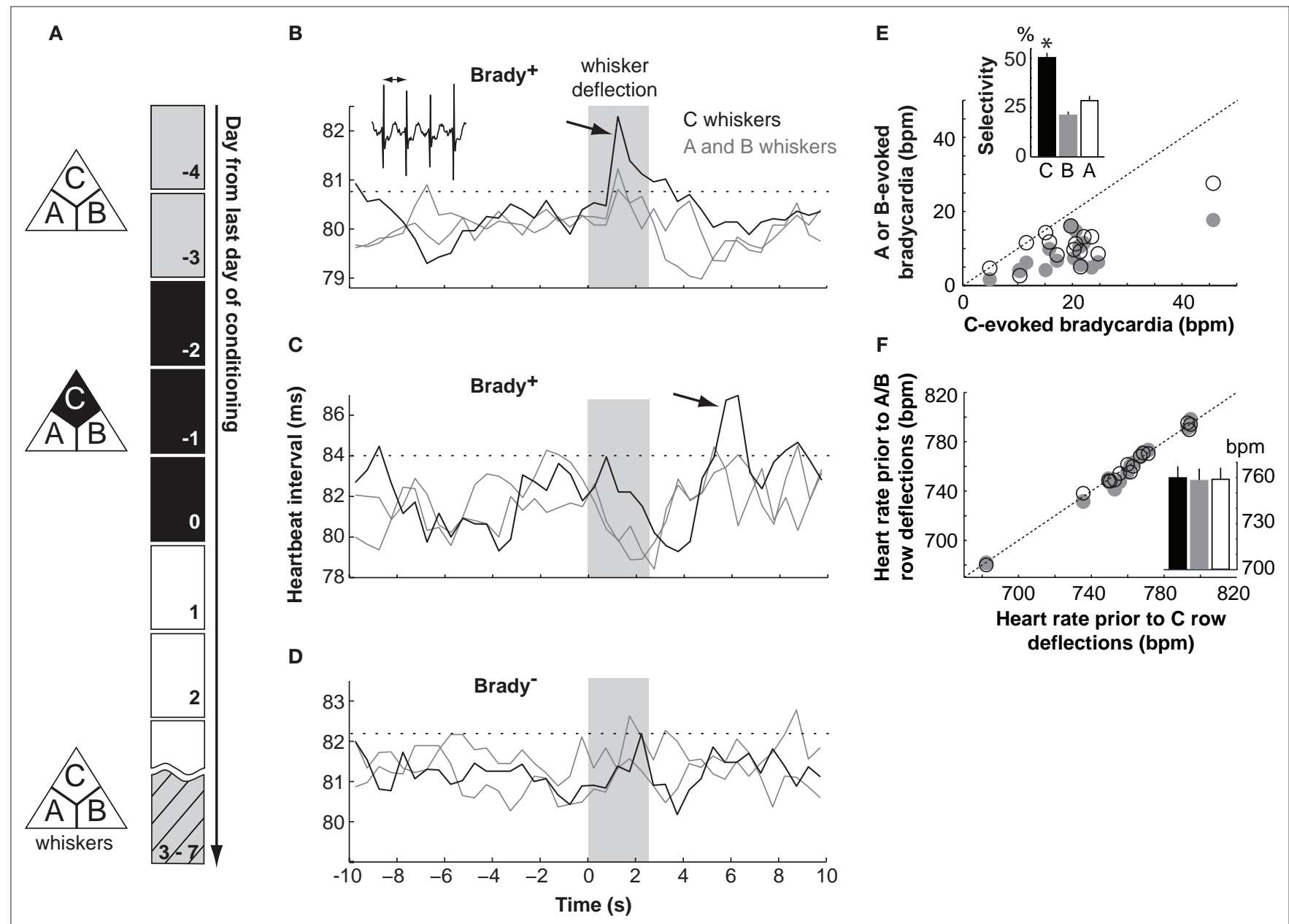

FIGURE 1 | Differential fear conditioning with the deflection of one whisker row as $\mathrm{CS}^{+}$. (A) The paradigm consisted of 2 days of habituation (gray), three of conditioning (black), and one of testing (hatched). (B-D) Electrocardiograms for two mice (B,C) showing a cardiac response $\left(\right.$ Brady $^{+}$mice) and one Brady mouse (D) on the testing day. Traces show the mean heartbeat intervals ( $0.5 \mathrm{~s}$ bins) in response to deflections of the $A, B$, and $C$ whisker rows (shaded area). The arrows point to bradycardias and the dashed lines indicate the threshold of significant bradycardias $\left(2 \times \mathrm{SD}_{\text {baseline }}\right)$. In inset, heartbeats. (E) Amplitude of bradycardias evoked by the deflection of $A$ (open symbol) and B (gray) whiskers as a function of the amplitude of bradycardias evoked by the deflection of $\mathrm{C}$ whiskers for each Brady+ mouse. In inset the selectivity of cardiac response evoked by the A, B, and C whiskers. Mice showed bradycardias of greater amplitudes at the deflection of $C$ whiskers. The star indicates $p<0.02$ (Wilcoxon). (F) Same as in (E) for the heart rate in baseline prior to cardiac responses. In inset, the mean heart rate prior to $C$ (black), $B$ (gray), and $A$ (open)-evoked cardiac responses. previously reported in (Bureau et al., 2006). Therefore, L4 inputs presented from now on originated from the upper two-thirds of barrels only.

The enhanced L5A inputs in $\mathrm{Brady}^{+}$mice originated from the center of the B column and were increased twofolds compared to naive mice (from $6.1 \pm 1.4$ to $13.0 \pm 2.8 \mathrm{pA}$; $p<0.05$; Figure $2 \mathrm{G}$ ). In contrast, the additional $\mathrm{L} 2 / 3$ inputs were from presynaptic cells laterally distant by $190-410 \mu \mathrm{m}$ from the center of the B column and were located in the paired $\mathrm{C}$ column and in the area above septum between $B$ and $C(+72 \%$; from $3.9 \pm 0.6$ to $6.7 \pm 1.4 \mathrm{pA}$; $p<0.05)$. Input from this region in $C$ was on average $1.7 \pm 0.3$ folds larger than its mirror input in $\mathrm{A}$ ( $p=0.05, t$-test). This spatial rearrangement shifted the center of mass (see Materials and Methods) of the global L2/3 synaptic input from the center of the B column in naive mice (offset, $0 \pm 13 \mu \mathrm{m}$ ) to a mean distance of $39 \pm 17 \mu \mathrm{m}$ toward $\mathrm{C}$ in Brady ${ }^{+}$mice $(p<0.05, t$-test).
The effects described above were specific to the B column: In the column of $\mathrm{CS}^{+}$(i.e., $\mathrm{C}$ column), conditioning did not significantly affect inputs from L2/3 and L5A compare to naive mice (4.2 \pm 0.7 , $5.0 \pm 1.4 \mathrm{pA}$, respectively; $n=17$; Figures $2 \mathrm{E}-\mathrm{G}$ ). In particular, L2/3 cells received $\mathrm{L} 2 / 3$ inputs from the $\mathrm{C}$ column only (center of mass offset, $20 \pm 19 \mu \mathrm{m}, p>0.3 t$-test). Conditioning did not significantly alter the $\mathrm{L} 4 \rightarrow \mathrm{L} 2 / 3$ projections in the $\mathrm{C}$ column either, because mean inputs from the barrel were $22.0 \pm 4.0 \mathrm{pA}$ in naive mice and $25.6 \pm 5.7 \mathrm{pA}$ in $\mathrm{Brady}^{+}$mice. Thus, our data show that behavioral conditioning strengthened excitatory circuits feeding into L2/3 only in columns corresponding to unpaired stimuli.

\section{DISTINCT PLASTICITY IN L2 AND L3}

Cells in L2/3 of barrel cortex, often sampled in a single group, are potentially integrated in distinct neuronal pathways of sensory integration (Bureau et al., 2006; Lefort et al., 2009). Thus, we next 


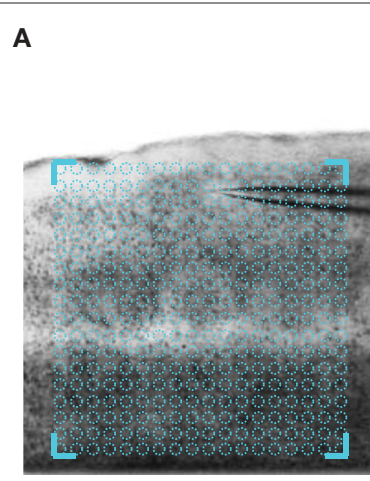

B

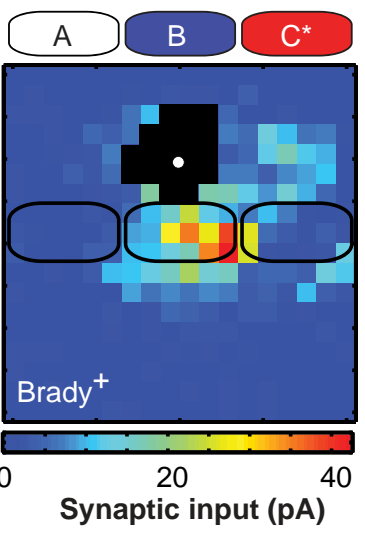

D

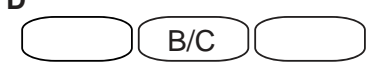

F

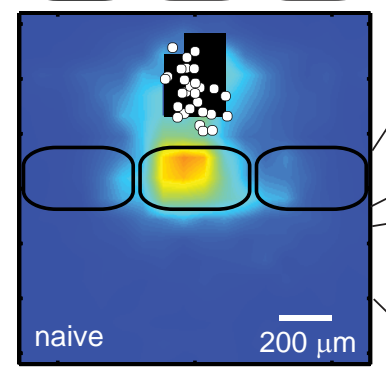

E

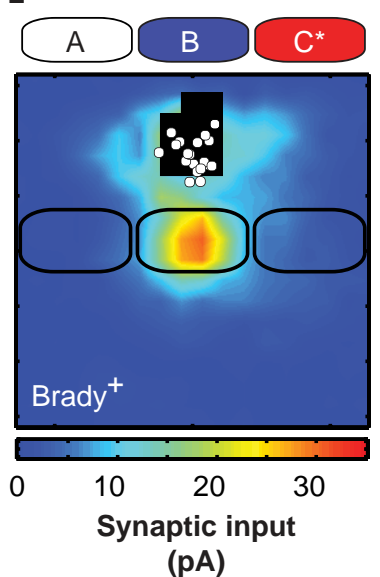

(pA)

FIGURE 2 | Plasticity of excitatory circuits targeting L2/3 in columns of unpaired whiskers. (A) Across-barrel slice showing the A-E barrels. Here, the uncaging grid (blue) was centered on the $C$ barrel. (B) Examples of synaptic input maps for $L 2 / 3$ cells located in the B barrel of two Brady ${ }^{+}$mice. Colors indicate the amplitude of synaptic responses. Black pixels are sites with direct glutamate-evoked responses. The solid white circle shows the soma position of the recorded neuron. Solid black lines are barrels. (C) Direct responses were detected immediately after the UV pulse (arrow head). Synaptic responses had longer latencies and were measured in a 50-ms time window, 6 ms after the

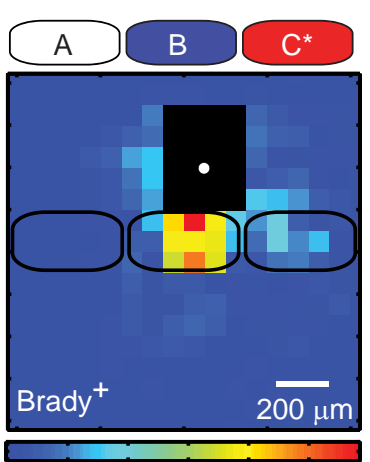

C

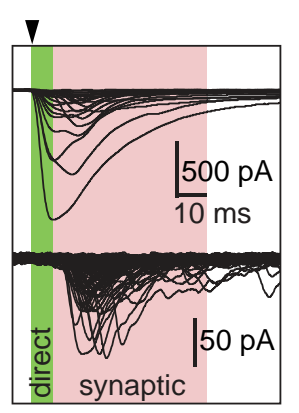

0

G

Synaptic input (pA)
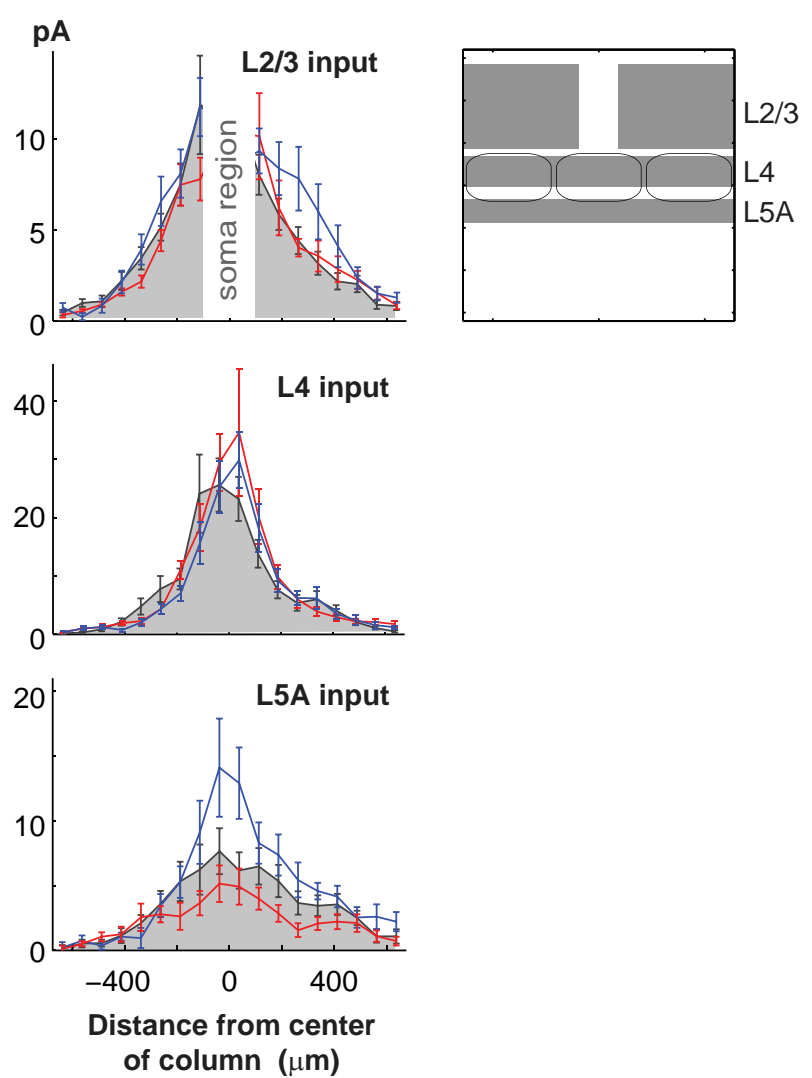

pulse (pink). (D) Average synaptic input map for naive mice $(n=28)$. Maps centered over the $\mathrm{B}(n=17)$ and $\mathrm{C}(n=11)$ columns were pooled as they were similar. (E) Synaptic input maps for Brady ${ }^{+}$mice centered over the B column (left, $n=19$ ) and the $C$ column (right, $n=17)$. (F) Vertical profile (75 $\mu \mathrm{m}$ bins) of synaptic inputs for $L 2 / 3$ cells recorded in naive mice (solid gray) and for $L 2 / 3$ cells recorded in the $B$ (blue) and $C$ (red) columns of Brady ${ }^{+}$mice. (G) Horizontal profiles of synaptic inputs received by $L 2 / 3$ cells in naive (solid gray) and Brady ${ }^{+}$ mice (B column, blue; $\mathrm{C}$ column, red). In insets, the regions where the synaptic inputs were measured. examined how conditioning affected their inputs separately. In the absence of a clear cytoarchitectural demarcation of the L2/L3 boundary, we divided the supragranular layer in two: hereafter L2 and L3 refer to the upper half and lower half, respectively.
In naive mice, L2 cells received twice as much $\mathrm{L} 2 / 3$ inputs from distant cells, located $260-410 \mu \mathrm{m}$ away from the center of column, compared to L3 cells (L2 cells, $8.6 \pm 2.1 \mathrm{pA} ; n=14$; L3 cells, $3.9 \pm 0.8$ pA; $n=14 ; p<0.05$, $t$-test; Figures $3 A-C)$. L2 and 


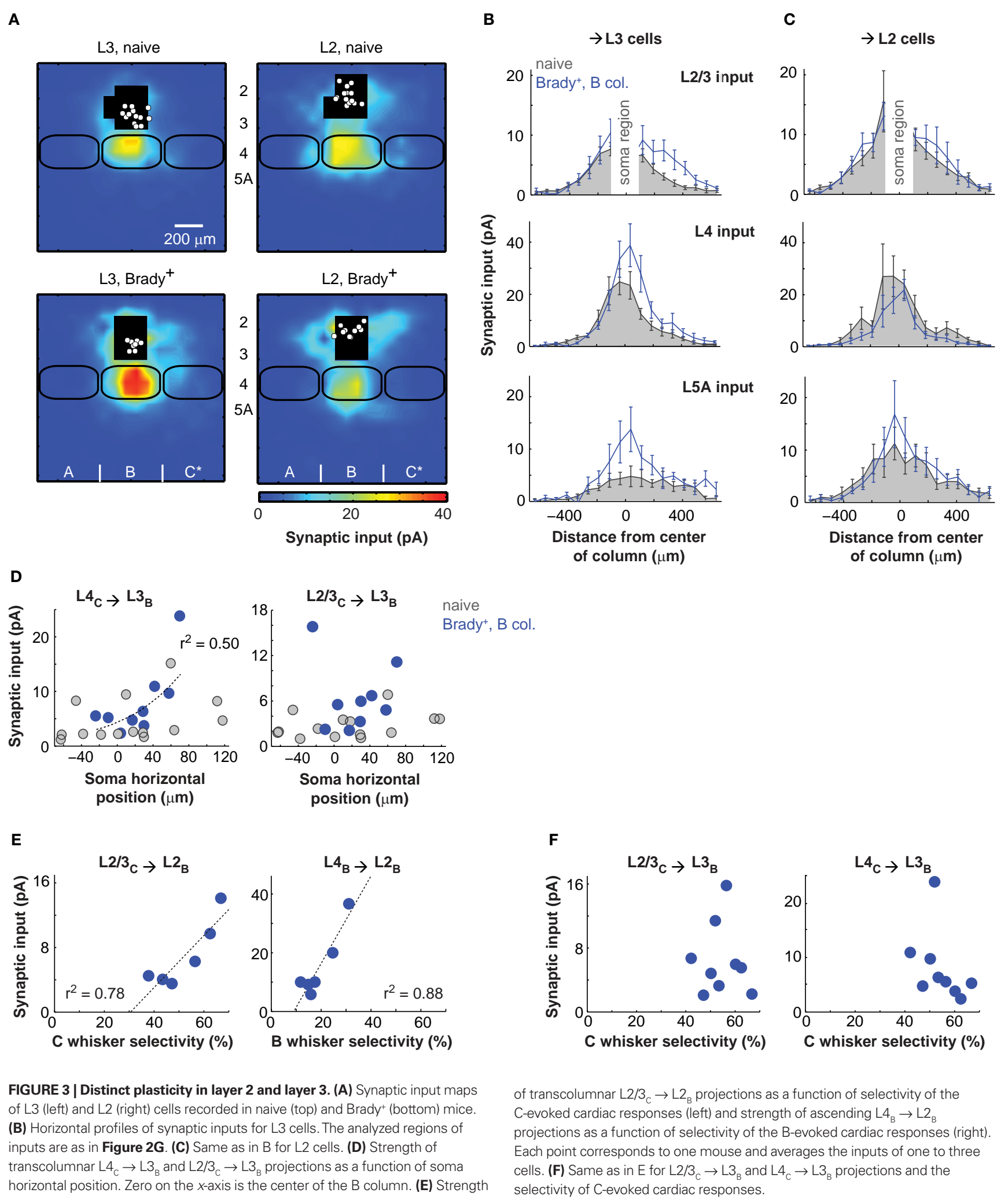

L3 cells also differed by their L5A inputs, larger for the former (L2, $11.2 \pm 3.1 \mathrm{pA}$; L3 cells, $4.4 \pm 1.2 \mathrm{pA} ; p<0.05$, $t$-test). We found the difference between L2 and L3 cells more pronounced in a previous study because L2 cells exhibited weaker L4 inputs then (Bureau et al., 2006). As L2 neurons mature last in cortex, the age of the animals ( 2 weeks older here) could explain the difference. 
The L2/L3 functional division was even more evident when examining the effects of conditioning: First, the strengthening of L2/3 and L5A inputs was only statistically significant for pyramids with cell body in L3 ( $n=9$; Figure 3B). L5A inputs measured at the center of the $\mathrm{B}$ column increased by a factor of three there (from $4.8 \pm 2.0$ to $13.8 \pm 4.6 \mathrm{pA} ; p<0.05$ ) and $\mathrm{L} 2 / 3$ inputs measured with a lateral offset of $190-410 \mu \mathrm{m}$ toward the paired $\mathrm{C}$ column increased by a factor of two (from $2.7 \pm 0.4$ to $6.4 \pm 1.5 \mathrm{pA} ; p<0.05$; center of mass offset, $68 \pm 20 \mu \mathrm{m}, p<0.05 t$-test). Second, separating L2 and L3 cells revealed a strengthening of L4 $\rightarrow$ L3 projections (Figure 3B). This effect was non-uniform and targeted projections originating from the part of the $\mathrm{B}$ barrel facing $\mathrm{C}$, the $\mathrm{B} / \mathrm{C}$ septum and part of the $\mathrm{C}$ barrel (Figure 2B for an example). Inputs from these projections (lateral distance from the B column center, $190-490 \mu \mathrm{m})$ increased twofolds from $4.7 \pm 1.1 \mathrm{pA}$ in naive mice to $8.1 \pm 2.2 \mathrm{pA}$ in $\mathrm{Brady}^{+}$mice $(p<0.05)$. As a consequence, conditioning shifted the center of mass of global L4 inputs received by $\mathrm{L} 3$ cells from $9 \pm 20 \mu \mathrm{m}$ in naive mice to $51 \pm 12 \mu \mathrm{m}$ toward C in Brady $^{+}$mice $(p<0.05)$.

The effect of conditioning was function $\left(r^{2}=0.5\right)$ of the L 3 cell position in the B column: the closer their somata to the $\mathrm{C}$ column, the stronger their L4 inputs originating from $\mathrm{C}$ (Figure 3D). This correlation did not apply to their L2/3 inputs.

Synaptic input maps of L2 cells $(n=10)$ in Brady ${ }^{+}$mice were not statistically different from that of L2 cells in naive mice (Figure 3C). However, we found that the strength of horizontal L2/3 projections $\left(\mathrm{L} 2 / 3_{\mathrm{C}} \rightarrow \mathrm{L} 22_{\mathrm{B}}\right)$ in the Brady ${ }^{+}$group was greater for mice that had shown better capacity at discriminating the paired $\mathrm{C}$ whiskers (Figure 3E), as indicated by their higher selectivity index (same as in Figure 1E). Simultaneously, L2 cells had weaker L4 inputs from the $\mathrm{B}$ barrel when the animal was less responsive to the deflections of $\mathrm{B}$ whiskers. Similar comparisons between the strength of $\mathrm{L}_{\mathrm{C}} \rightarrow \mathrm{L} 3_{\mathrm{B}}$ and $\mathrm{L} 2 / 3_{\mathrm{C}} \rightarrow \mathrm{L} 3_{\mathrm{B}}$ projections and the selectivity of cardiac responses to $\mathrm{C}$ whisker deflections showed no correlation (Figure 3F).

\section{CORTICAL CIRCUITS ARE MODIFIED BY ASSOCIATIVE LEARNING}

To confirm whether the plasticity of cortical projections was related to the learning performance of the animals, we analyzed the same circuits in Brady ${ }^{-}$mice which had similar training but did not show a bradycardia at the presentation of $\mathrm{CS}^{+}$(Figure 4A). The strength of $\mathrm{L} 2 / 3$ inputs originating in the C column (lateral distance, 190$410 \mu \mathrm{m}$ ) and received by $\mathrm{L} 2 / 3$ cells or $\mathrm{L} 3$ cells alone in the B column did not increase compared to naive mice (L2/3 cells, $4.0 \pm 0.7 \mathrm{pA}$, $n=23$; L3 cells, $3.8 \pm 0.3 \mathrm{pA}, n=9)$. And unlike for $\mathrm{Brady}^{+}$mice, the center of mass of global L2/3 inputs was aligned with the $B$ barrel axis (offset, $-5 \pm 12 \mu \mathrm{m}$ for L2/3 cells and $14 \pm 16 \mu \mathrm{m}$ for L3 cells; Figures 4B,C). The lack of strengthening was also true for the $\mathrm{L} 4 \rightarrow \mathrm{L} 3$ projections from $\mathrm{C}$ to $\mathrm{B}$ (input, $4.3 \pm 0.9 \mathrm{pA}$; offset, $-17 \pm 17 \mu \mathrm{m}$ ) and the ascending $\mathrm{L} 5 \mathrm{~A} \rightarrow \mathrm{L} 3$ projections in $\mathrm{B}$ (input, $2.7 \pm 1.2 \mathrm{pA}$; Figures 4C,D).

We next examined these projections in pseudoconditioned mice for which whiskers deflections and tail shocks had not been paired during training (Figure 4A). L2/3 inputs originating in the $\mathrm{C}$ column and received by neurons in the B column were weak, like in naive and Brady ${ }^{-}$mice: $3.0 \pm 0.6 \mathrm{pA}$ for L2/3 cells $(n=19)$ and $2.3 \pm 0.5 \mathrm{pA}$ for L3 cells ( $n=12$; Figures $4 \mathrm{~B}-\mathrm{D})$. The lack of plasticity was also evident in the alignment of the center of mass of all $\mathrm{L} 2 / 3$ inputs with the B barrel vertical axis (offset for $\mathrm{L} 2 / 3$ cells, $-18 \pm 13 \mu \mathrm{m}$; offset for L3 cells, $-5 \pm 14 \mu \mathrm{m}$ ). Finally, pseudoconditioning did not affect the transcolumnar $\mathrm{L} 4 \rightarrow \mathrm{L} 3$ projections from $\mathrm{C}$ to $\mathrm{B}$ (input, $4.5 \pm 1.1 \mathrm{pA}$; offset, $4.0 \pm 15 \mu \mathrm{m}$ ) nor the ascending L5A $\rightarrow$ L3 projections within B (input, $3.3 \pm 0.9 \mathrm{pA}$; Figures 4C,D). Altogether, our data indicate that the plasticity of excitatory projections onto L2/3 cells was specific to the Brady ${ }^{+}$ group of mice (Figure 4D).

\section{DISCUSSION}

We studied the effects of differential conditioning on excitatory circuits of barrel cortex with LSPS mapping. We found multiple changes in projections targeting neurons in L2/3 which were crossing columnar boundaries. These might provide a cellular substrate for the transformation of the whisker somatotopic map induced by associative learning.

\section{LSPS MAPS LOCI OF LEARNING-DEPENDENT PLASTICITY IN CORTEX}

We found that combining behavioral trainings and LSPS mapping was a powerful approach to rapidly identify novel loci of learninginduced plasticity in the brain. Here, it permitted the identification of three different intracortical projections targeting L3 of barrel cortex. The correlation we found between the discrimination performance and the strength of projections targeting L2 suggests that this number could be raised to five. However, having a complete picture of learning-dependent events in L2/3 will require surveying the inhibitory projections (Helmstaedter et al., 2009) and the thalamocortical projections (Petreanu et al., 2009) innervating these layers.

We showed that plasticity in L2/3 was only seen in conditioned animals that made the association at the moment of the test. Because cardiac fear responses were not monitored during conditioning but only days later, we cannot conclude whether the lack of circuit changes in $\mathrm{Brady}^{-}$mice was linked to a failure to learn or to memory extinction. However, this result together with our observation that pseudoconditioning had no effect on the projections onto L2/3 show that plasticity in $\mathrm{Brady}^{+}$mice was the result of specific learning mechanisms and not the product of sensory experience only. How this cortical plasticity impacts learning remains unclear. One hypothesis is that its role varies as a function of difficulty of the task. Indeed, it was shown that lesions or inactivation of primary sensory cortices did not impair memory recall after classical conditionings (Hutson and Masterton, 1986; Galvez et al., 2007; Sacco and Sacchetti, 2010) but they did in demanding tasks such as differential conditioning (Jarrell et al., 1987), trace conditioning (Galvez et al., 2007), or operant conditioning (Hutson and Masterton, 1986; Guic-robles et al., 1992; Krupa et al., 2001; O’Connor et al., 2010).

Our study does not address the nature of the cellular mechanisms underlying the plasticity of projections targeting L3 cells. They could either be synaptic or non-synaptic (Bureau et al., 2008): Non-synaptic mechanisms affect the excitation evoked by LSPS (photo-excitation). They could include changes in the number of neurons located in the path of the laser beam and changes in neuron excitability. Learning-dependent increases of neuronal excitability are well documented (Bekisz et al., 2010); reviewed in (Daoudal and Debanne, 2003). However, an enhanced photoexcitation of presynaptic cells is unlikely to account for the stronger transcolumnar L4 $\rightarrow \mathrm{L} 3$ and $\mathrm{L} 2 / 3 \rightarrow \mathrm{L} 3$ projections from $\mathrm{C}$ to $\mathrm{B}$ 

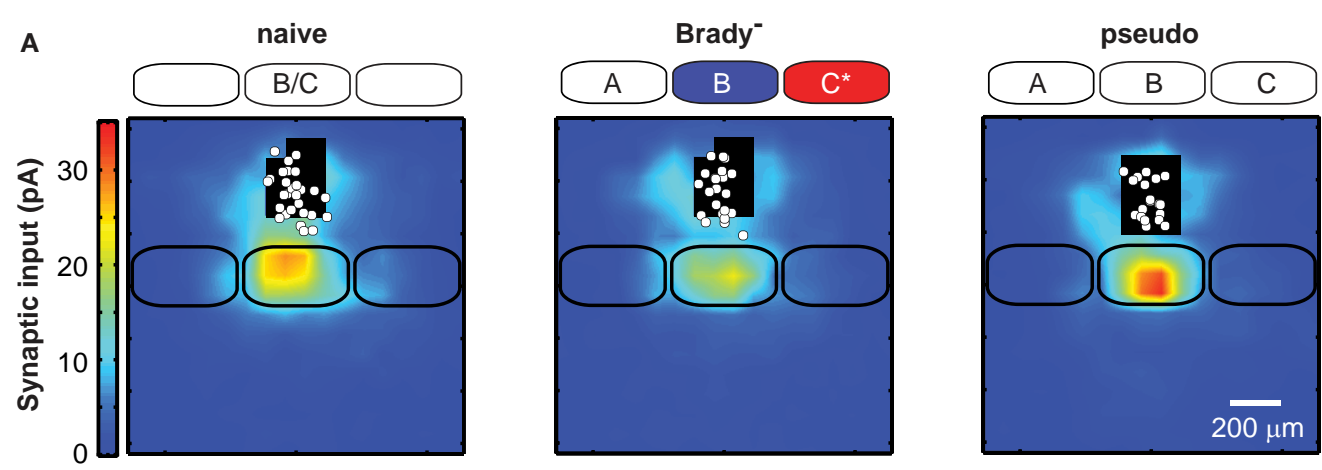

B
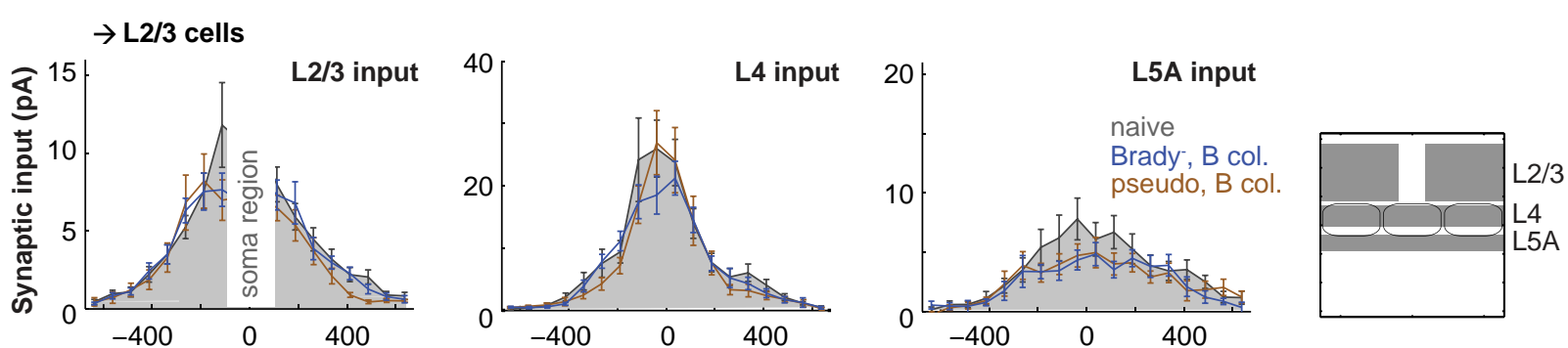

C
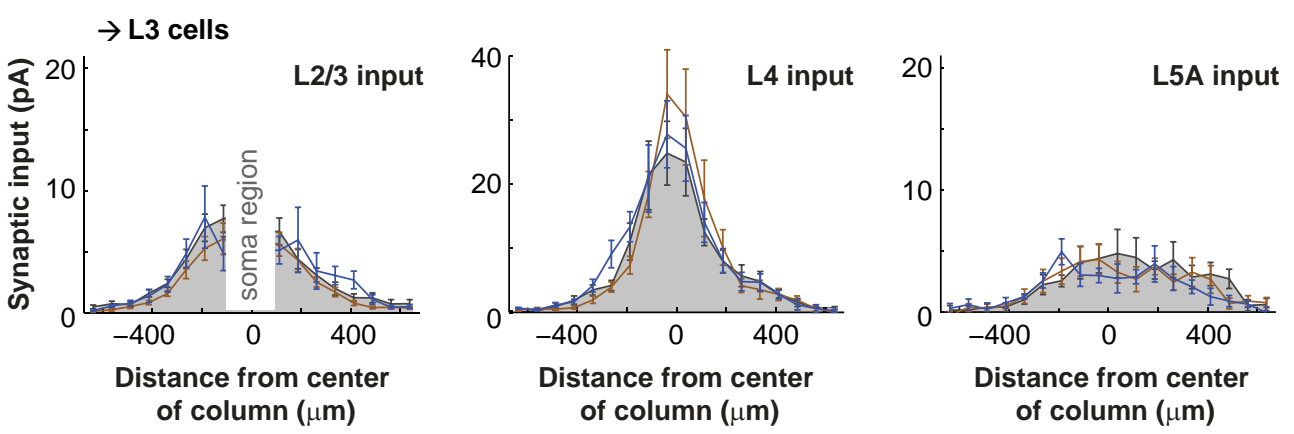

D
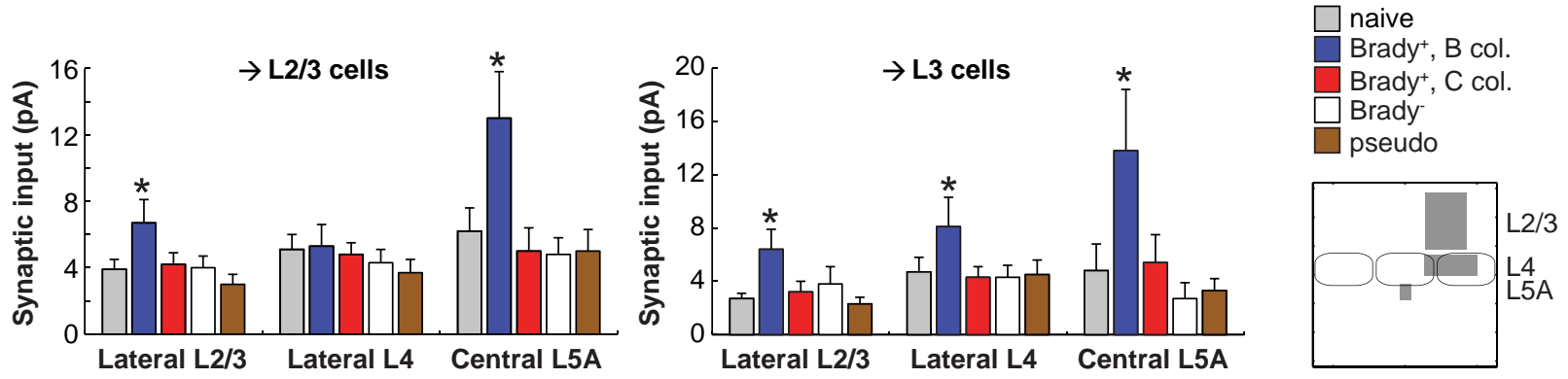

FIGURE 4 | Lack of plasticity in mice that did not show a cardiac fear response. (A) Synaptic input maps for naive mice (left, $n=28$ ), Brady mice (center, $n=23$ ), and for pseudoconditioned mice (right, $n=19$ ). Maps of Brady and pseudoconditioned mice were centered over the B column. (B) Horizontal profiles of synaptic inputs for $L 2 / 3$ cells recorded in naive mice (solid gray) and for $L 2 / 3$ cells recorded in the B column of Brady mice (blue) and

here because it would have similarly strengthened the columnar connections within C. In contrast, synaptic mechanisms affect the connectivity rate and the synaptic strength of unitary connections. Distinguishing between the two will require studying the properties of single connections. pseudoconditioned mice (brown). On the right, the analyzed regions of inputs are in gray. (C) Same as in B for L3 cells alone. (D) Summary of the effects of training on the synaptic inputs received by L2/3 and L3 cells in Brady+, Brady', and pseudoconditioned mice. The stars indicate statistically significant differences compared to naive mice ( $p<0.05$, Mann-Whitney). Regions of analysis are on the schematized map (right).

The strengthening of excitatory circuits we described could be accompanied by changes in inhibitory projections impinging onto L2/3 cells. However it is unlikely that (dis)inhibition interfered with our measurements because: (i) Synaptic responses were recorded at the reversal potential of inhibitory currents; (ii) The fraction 
of GABAergic interneurons was $\sim 15 \%$ (Beaulieu, 1993) at each photo-stimulated site; (iii) It was previously shown that there is no disynaptic excitation of inhibitory (or excitatory) neurons in our conditions (Shepherd et al., 2003; Bureau et al., 2008). This implies that the synaptic release of GABA would have to be evoked monosynaptically to shunt the excitatory synaptic currents. However, conditioning affected projections originating from L5A and from L4 and L2/3 of the neighboring column where the density of connected interneurons was low (Katzel et al., 2010). Points (ii) and (iii) suggest that the simultaneous photo-excitation of excitatory and inhibitory neurons connected to one same remote $\mathrm{L} 2 / 3$ pyramidal cell was atypical in these regions of the map.

\section{ASSOCIATIVE LEARNING CHANGES THE ORGANIZATION OF FUNCTIONAL INTRACORTICAL CIRCUITS IN BARREL CORTEX}

Different forms of sensory experience induce a transformation of the whisker map in the barrel cortex but few were investigated at the cellular level to the extent of partial sensory deprivations. These shift the receptive fields of neurons located in columns of clipped whiskers toward the spared vibrissa (Fox, 1992). It was thus interesting to learn whether differential conditioning and partial sensory deprivations affected the same group of projections since both paradigms give a competitive advantage to one particular whisker or set of whiskers.

Barrels are major entry points into cortex for sensory inputs carried by thalamocortical projections from the ventral posteromedial nucleus (VPM; Lu and Lin, 1993) and they provide strong excitatory inputs to L2/3 neurons (Petersen and Sakmann, 2001). Both projections have a precise somatotopic organization (Agmon et al., 1995; Lubke et al., 2003). Hence, L4 $\rightarrow$ L2/3 projections are an obvious site for investigating the mechanisms underlying the plasticity of the whisker map as they are instrumental in shaping the receptive fields of $\mathrm{L} 2 / 3$ neurons. This was previously illustrated with the effects of partial sensory deprivations which enhanced the synaptic strength of L4 $\rightarrow$ L2/3 connections in columns of spared whiskers (Finnerty et al., 1999; Clem and Barth, 2006) and reduced it in columns of clipped whiskers (Allen et al., 2003). Our data suggest that neither of these mechanisms occurred in the columns of the paired and unpaired whiskers after conditioning. This concurs with the findings that the intensity of metabolic activity evoked by paired and unpaired whiskers was stable in their corresponding columns (Siucinska and Kossut, 1996; Kossut and Siucinska, 1998). Only the spatial extent of the activity evoked by the paired whisker increased then. Interestingly, the observation that the ascending L4 $\rightarrow \mathrm{L} 2 / 3$ projections were not weaker in the columns of unpaired whiskers implies that inputs from $\mathrm{CS}^{-}$and $\mathrm{CS}^{+}$converged onto L2/3 neurons after conditioning and that the advantage given to one whisker did not induce competition between synapses nor homeostasis.

Our results suggest that a depression of L4 projections in columns of unpaired whiskers could still play a role in learning by raising the discrimination performance: This was suggested by the correlation of weak $\mathrm{L} 4 \rightarrow \mathrm{L} 2$ projections that we measured in these columns with the low levels of fear response evoked by unpaired whiskers (Figure 3D). Nevertheless, our data indicate that the major excitatory projections feeding into L $2 / 3$ is not the principal target of the effects of differential conditioning.
Instead, fear conditioning strengthened projections that were either weak or mute in the naive brain: the ascending $\mathrm{L}_{5} \mathrm{~A}_{\mathrm{B}} \rightarrow \mathrm{L} 3_{\mathrm{B}}$ and the transcolumnar $\mathrm{L} 2 / 3_{\mathrm{C}} \rightarrow \mathrm{L}_{\mathrm{B}}$ and $\mathrm{L} 4_{\mathrm{C}} \rightarrow \mathrm{L} 3_{\mathrm{B}}$ projections. One understands how the strengthening of transcolumnar $\mathrm{L} 2 / 3_{\mathrm{C}} \rightarrow \mathrm{L} 3_{\mathrm{B}}$ and $\mathrm{L}_{\mathrm{C}} \rightarrow \mathrm{L}_{\mathrm{B}}$ projections could permit an enlarged $\mathrm{CS}^{+}$representation in the whisker map: after reaching their corresponding column through the thalamocortical projections innerving L4 and then through $\mathrm{L} 4 \rightarrow \mathrm{L} 2 / 3$ projections, $\mathrm{CS}^{+}$inputs could propagate to the neighboring columns through horizontal L2/3 $\rightarrow \mathrm{L} 2 / 3_{\mathrm{B}}$ and $\mathrm{L} 4_{\mathrm{C}} \rightarrow \mathrm{L} 3_{\mathrm{B}}$ projections (Figure 5). Transcolumnar projections were shown to shape the whisker maps after partial sensory deprivations (Fox, 1994). However, the synaptic strength of $\mathrm{L} 2 \rightarrow \mathrm{L} 2$ connections originating in columns of spared whiskers and targeting the columns of clipped whiskers were shown to increase with the same magnitude than the inverse connections (Finnerty et al., 1999). In our experiments, fear conditioning strengthened projections targeting columns of unpaired whiskers specifically. Moreover, it strengthened transcolumnar L4 ${ }_{\mathrm{C}} \rightarrow \mathrm{L}_{\mathrm{B}}$ projections, an unforeseen effect considering that columnar organization was shown to be a robust feature of the functional L4 $\rightarrow$ L3 projections, even after sensory deprivations (Shepherd et al., 2003). Indeed, L4 cell axons innervate preferentially the region in L2/3 aligned with their barrel of origin but a fraction was shown to extend more laterally in neighboring columns (Lubke et al., 2003). These could provide the anatomical template for the functional transcolumnar $\mathrm{L}_{\mathrm{C}} \rightarrow \mathrm{L}_{\mathrm{B}}$ projections we detected after conditioning.

The consequences of the L5A $\rightarrow$ L3 plasticity are less clear as the spatial distribution of L5A cells did not show a bias for the column of $\mathrm{CS}^{+}$. The strength of these projections was also increased

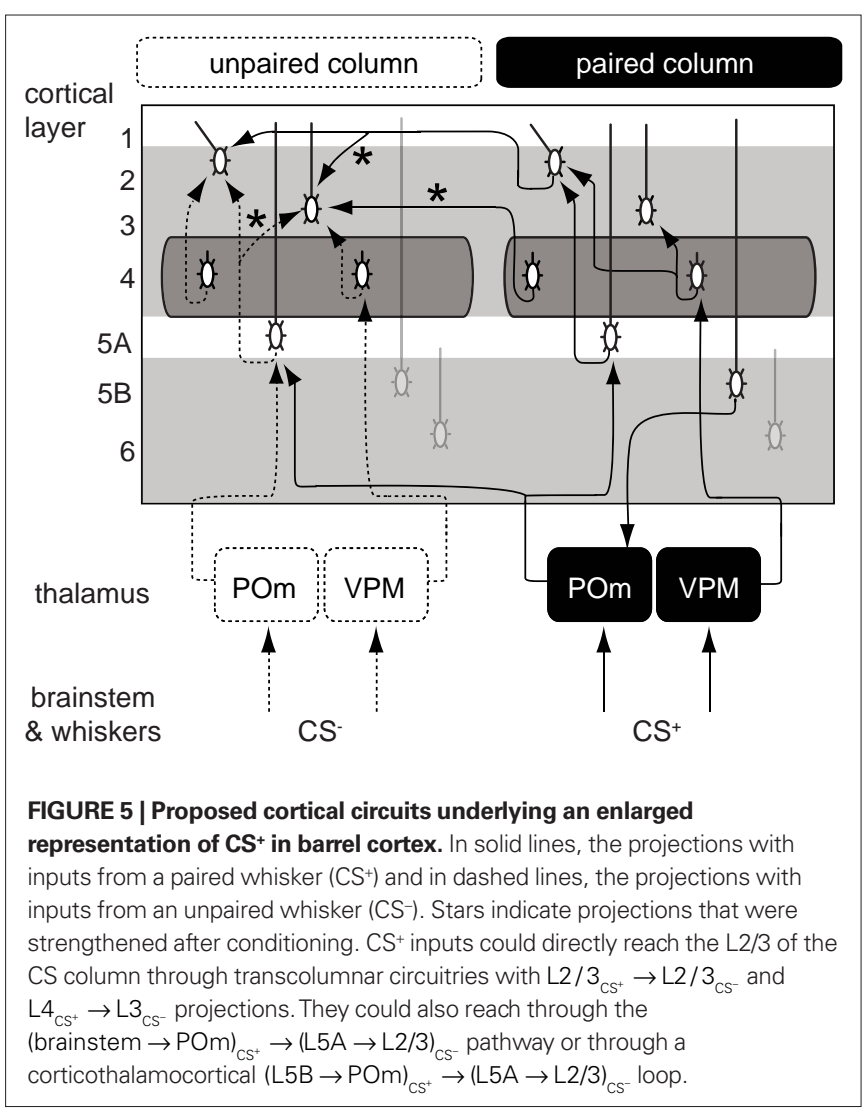


in sensory deprived mice (Bureau et al., 2008) suggesting that it contributes to the plasticity of the whisker map. Major projections to L5A are from the posterior medial nucleus of thalamus (POm; Deschenes et al., 1998; Bureau et al., 2006) and from L4 neurons (Schubert et al., 2006). The former lack somatotopic precision, overlapping with several columns, and could in theory carry $\mathrm{C}$ whisker inputs to the L5A of the B column (Figure 5). However, in vivo L5A cells exhibit sharp receptive fields suggesting that their dominant inputs are from nearby L4 cells in naive animals (Manns et al., 2004). Investigating the effects of conditioning in L5A should clarify the consequences of stronger L5A $\rightarrow \mathrm{L} 3$ projections on the shape of the whisker cortical map.

\section{REFERENCES}

Agmon, A., Yang, L. T., Jones, E. G., and O’Dowd, D. K. (1995). Topological precision in the thalamic projection to neonatal mouse barrel cortex. $J$. Neurosci. 15, 549-561.

Allen, C. B., Celikel, T., and Feldman, D. E. (2003).Long-term depression induced by sensory deprivation during cortical map plasticity in vivo. Nat. Neurosci. 6, 291-299.

Beaulieu, C. (1993). Numerical data on neocortical neurons in adult rat, with special reference to the GABA population. Brain Res. 609, 284-292.

Bekisz, M., Garkun, Y., Wabno, J., Hess, G., Wrobel, A., and Kossut, M. (2010). Increased excitability of cortical neurons induced by associative learning: an ex vivo study. Eur. J. Neurosci. 32, 1715-1725.

Bureau, I., Shepherd, G. M., and Svoboda, K. (2008). Circuit and plasticity defects in the developing somatosensory cortex of FMR1 knock-out mice. J. Neurosci. 28, 5178-5188.

Bureau, I., von Saint Paul, F., and Svoboda, K. (2006). Interdigitated paralemniscal and lemniscal pathways in the mouse barrel cortex. PLoS Biol. 4, e382. doi: 10.1371/journal.pbio.0040382

Callaway, E. M., and Katz, L. C. (1993). Photostimulation using caged glutamate reveals functional circuitry in living brain slices. Proc. Natl. Acad. Sci. U.S.A. 90, 7661-7665.

Clem, R. L., and Barth,A. (2006). Pathwayspecific trafficking of native AMPARs by in vivo experience. Neuron 49 , 663-670.

Daoudal, G., and Debanne, D. (2003). Long-term plasticity of intrinsic excitability: learning rules and mechanisms. Learn. Mem. 10, 456-465.

Deschenes, M., Veinante, P., and Zhang, Z. W. (1998). The organization of corticothalamic projections: reciprocity versus parity. Brain Res. Rev. 28, 286-308.

Edeline, J. M. (1999). Learning-induced physiological plasticity in the thalamo-cortical sensory systems: a critical evaluation of receptive field plasticity, map changes and their potential mechanisms. Prog. Neurobiol. 57, 165-224.

Feldmeyer, D., Lubke, J., and Sakmann, B. (2006). Efficacy and connectivity of intracolumnar pairs of layer $2 / 3$ pyramidal cells in the barrel cortex of juvenile rats. J. Physiol. 575, 583-602.

Feldmeyer, D., Roth, A., and Sakmann, B. (2005). Monosynaptic connections between pairs of spiny stellate cells in layer 4 and pyramidal cells in layer $5 \mathrm{~A}$ niscal afferent pathways converge in the infragranular somatosensory cortex. J. Neurosci. 25, 3423-3431.

Finnerty, G. T., Roberts, L. S. E., and Connors, B.W. (1999). Sensory experience modifies the short-term dynamics of neocortical synapses. Nature 400 , 367-371.

Fox, K. (1992). A critical period for experience-dependent synaptic plasticity in rat barrel cortex. J. Neurosci. 12, 1826-1838.

Fox, K. (1994). The cortical component of experience-dependent synaptic plasticity in the rat barrel cortex. J. Neurosci. 14, 7665-7679.

Galvez, R., Weible, A. P., and Disterhoft, J. F. (2007). Cortical barrel lesions impair whisker-CS trace eyeblink conditioning. Learn. Mem. 14, 94-100.

Galvez, R., Weiss, C., Weible, A. P., and Disterhoft, J. F. (2006). Vibrissasignaled eyeblink conditioning induces somatosensory cortical plasticity. J. Neurosci. 26, 6062-6068.

Gierdalski, M., Jablonska, B., Siucinska, E., Lech, M., Skibinska, A., and Kossut, M. (2001). Rapid regulation of GAD67 mRNA and protein level in cortical Cortex 11, 806-815.

Guic-robles, E., Jenkins, W. M., and Bravo, H. (1992). Vibrissal roughness discrimination is barrelcortex-dependent. Behav. Brain Res. 48, 145-152.

Helmstaedter, M., Sakmann, B., and Feldmeyer, D. (2009). Neuronal correlates of local, lateral, and translaminar inhibition with reference to cortical columns. Cereb. Cortex 19, 926-937. indicate that lemniscal and paralemneurons after sensory learning. Cereb.
To conclude, associative learning binds neighboring cortical columns together through the strengthening of intracortical transcolumnar circuits. This phenomenon could serve the amplification of stimuli tagged with emotions in the primary somatosensory cortex.

\section{ACKNOWLEDGMENTS}

We thank O. Manzoni, J. M, Edeline, J. Epsztein, L. Le Goff, and M. Maravall for their comments on the manuscript. The work was supported by the Avenir program of INSERM, Career Development Award from Human Frontier Science Program, International Reintegration Grant from Europe FP7, general council of Bouchesdu-Rhône, and Fondation pour la Recherche Médicale.

Hubel, D. H., and Wiesel, T. N. (1962). Receptive fields, binocular interaction and functional architecture in the cat's visual cortex. J. Physiol. 160, 106-154.

Hutson, K. A., and Masterton, R. B. (1986). The sensory contribution of a single vibrissa's cortical barrel. $J$. Neurophysiol. 56, 1196-1223.

Jarrell, T. W., Gentile, C. G., Romanski, L. M., Mccabe, P. M., and Schneiderman, N. (1987). Involvement of cortical and thalamic auditory regions in retention of differential bradycardiac conditioning to acoustic conditioned-stimuli in rabbits. Brain Res. 412, 285-294.

Katzel, D., Zemelman, B. V., Buetfering, C., Wolfel, M., and Miesenbock, G. (2010). The columnar and laminar organization of inhibitory connections to neocortical excitatory cells. Nat. Neurosci. 14, 100-107.

Kossut, M., and Siucinska, E. (1998). Learning-induced expansion of cortical maps-what happens to adjacent cortical representations? Neuroreport 9, 4025-4028.

Krupa, D. J., Matell, M. S., Brisben, A. J., Oliveira, L. M., and Nicolelis, M. A. L. (2001). Behavioral properties of the trigeminal somatosensory system in rats performing whisker-dependent tactile discriminations. J. Neurosci. 21 , 5752-5763.

Lefort, S., Tomm, C., Sarria, J. C. F., and Petersen, C. C. H. (2009). The excitatory neuronal network of the $\mathrm{C} 2$ barrel column in mouse primary somatosensory cortex. Neuron 61 , 301-316.

Lu, S.M., and Lin, R. C. S. (1993). Thalamic afferents of the rat barrel cortex: a lightand electron-microscopic study using Phaseolus vulgaris leucoagglutinin as an anterograde tracer. Somatosens. Mot. Res. 10, 1-16.

Lubke, J., Roth, A., Feldmeyer, D., and Sakmann, B. (2003). Morphometric analysis of the columnar innervation domain of neurons connecting layer 4 and layer $2 / 3$ of juvenile rat barrel cortex. Cereb. Cortex 13 1051-1063.
Manns, I. D., Sakmann, B., and Brecht, M. (2004). Sub- and suprathreshold neurones in layers $5 \mathrm{~A}$ and $5 \mathrm{~B}$ of rat somatosensory barrel cortex. J. Physiol. 556, 601-622.

Marchand, A. R. (2002). Integration of cardiac responses to serial stimuli after Pavlovian conditioning in rats. Anim. Learn. Behav. 30, 132-142.

Martin, G. K., and Fitzgerald, R. D. (1980). Heart rate and somatomotor activity rats during signalled escape and yoked classical conditioning. Physiol. Behav. 25, 519-526.

Mountcastle, V. B. (1957). Modality and topographic properties of single neurons of cat's somatic sensory cortex. J. Neurophysiol. 20, 408-434.

O'Connor, D. H., Clack, N. G., Huber, D., Komiyama, T., Myers, E. W., and Svoboda, K. (2010). Vibrissa-based object localization in head-fixed mice. J. Neurosci. 30, 1947-1967.

Petersen, C. C., and Sakmann, B. (2001). Functionally independent columns of rat somatosensory barrel cortex revealed with voltage-sensitive dye imaging. J. Neurosci. 21, 8435-8446.

Petreanu, L., Mao, T. Y., Sternson, S. M., and Svoboda, K. (2009). The subcellular organization of neocortical excitatory connections. Nature 457, 1142-1145.

Sacco, T., and Sacchetti, B. (2010). Role of secondary sensory cortices in emotional memory storage and retrieval in rats. Science 329, 649-656.

Schubert, D., Kotter, R., Luhmann, H. J., and Staiger, J. F. (2006). Morphology, electrophysiology and functional input connectivity of pyramidal neurons characterizes a genuine layer $\mathrm{Va}$ in the primary somatosensory cortex. Cereb. Cortex 16, 223-236.

Shepherd, G. M. G., Pologruto, T. A., and Svoboda, K. (2003). Circuit analysis of experience-dependent plasticity in the developing rat barrel cortex. Neuron 38, 277-289.

Shepherd, G. M. G., and Svoboda, K. (2005). Laminar and columnar organization of ascending excitatory projections to receptive field properties of pyramidal 
layer $2 / 3$ pyramidal neurons in rat barrel cortex. J. Neurosci. 25, 5670-5679.

Siucinska, E., and Kossut, M. (1996). Shortlasting classical conditioning induces reversible changes of representational maps of vibrissae in mouse SI cortex-a 2DG study. Cereb. Cortex 6, 506-513.

Siucinska, E., and Kossut, M. (2004). Experience-dependent changes in cortical whisker representation in the adult mouse: a 2-deoxyglucose study. Neuroscience 127, 961-971.

Siucinska, E., Kossut, M., and Stewart, M. G. (1999). GABA immunoreactivity in mouse barrel field after aversive and appetitive classical conditioning training involving facial vibrissae. Brain Res. 843, 62-70.
Suter, B. A., O'Connor, T., Iyer, V., Petreanu, L. T., Hooks, B. M., Kiritani, T., Svoboda, K., and Shepherd, G. M. G. (2010). Ephus: multipurpose data acquisition software for neuroscience experiments. Front. Neurosci. 4:53. doi: 10.3389/fnins.2010.00053

Tokarski, K., Urban-Ciecko, J., Kossut, M., and Hess, G. (2007). Sensory learninginduced enhancement of inhibitory synaptic transmission in the barrel cortex of the mouse. Eur. J. Neurosci. 26, 134-141.

Weiler, N., Wood, L., Yu, J., Solla, S. A., and Shepherd, G. M. (2008). Topdown laminar organization of the excitatory network in motor cortex. Nat. Neurosci. 11, 360-366.
Weinberger,N.M.(2004).Specificlong-term memory traces in primary auditory cortex. Nat. Rev. Neurosci. 5, 279-290.

Woolsey, T. A., and Loos, H. v. d. (1970). The structural organization of layer IV in the somatosensory region (S1) of mouse cerebral cortex. Brain Res. 17, 205-242.

Conflict of Interest Statement: The authors declare that the research was conducted in the absence of any commercial or financial relationships that could be construed as a potential conflict of interest.

Received: 20 October 2010; paper pending published: 06 December 2010; accepted:
29 December 2010; published online: 14 January 2011.

Citation: Rosselet C, Fieschi M, Hugues $S$ and Bureau I (2011) Associative learning changes the organization of functional excitatory circuits targeting the supragranular layers of mouse barrel cortex. Front. Neural Circuits 4:126. doi: 10.3389/ fncir.2010.00126

Copyright (c) 2011 Rosselet, Fieschi, Hugues and Bureau. This is an openaccess article subject to an exclusive license agreement between the authors and the Frontiers Research Foundation, which permits unrestricted use, distribution, and reproduction in any medium, provided the original authors and source are credited. 